\title{
Demonstration of pseudorabies virus DNA in the mouse inner ear by an in situ nucleic acid hybridization technique in plastic embedded bony material
}

\author{
by N. Fal.ser, I. Bandtlow, M. Haus ${ }^{\star}$ and H. WOLF ${ }^{\star}$, Department of \\ Oto-Rhino-Laryngology, University of Innsbruck, Austria, and ${ }^{\star}$ Department of Molecular \\ and Tumour Virology, Max-v. Pettenkofer Institute, University of Munich, F.R.G.
}

KEY WORDS. Autoradiography, bone, cytological techniques, DNA, viral, hybridization, labyrinth diseases, microscopy, methylmethacrylates, neural pathways, preservation, biological, pseudorabies virus, virus diseases.

SUMMARY

This investigation is concerned with the possibility of identifying viral DNA using the in situ DNA hybridization method in methylmethacrylate-embedded material. As an experimental model we chose viral labyrinthitis produced by intranasal infection of the mouse with pseudorabies virus. Fixation and embedding methods specially adapted to this procedure and bony histology preparation technique (specimens by grinding or micromilling) made it possible to identify viral DNA directly morphologically and virologically in the inner ear. Quantitative microphotometric analyses of trans-sagittal sections of the entire skull after in situ DNA hybridization are presented and discussed here as an explicit method of investigating the path of distribution of viral DNA in the brain and the inner ear.

\section{INTRODUCTION}

The technique of in situ hybridization of tissue sections of virus infected material is the only molecular virological method which permits viral nucleic acids to be related to morphological structures at the light microscope level (Edwards \& Wood, 1983). The method is based on labelling double-stranded viral DNA extracted from infected cells or obtained from recombinant plasmid clones with a radioactive nucleotide by nick-translation (Rigby et al., 1977) and subsequent denaturation in single strands. During the hybridization process these labelled single viral DNA strands react with the similarly denatured unlabelled DNA in the sections of the specimen if viral DNA is present.

By hybridization of the added labelled viral DNA from the tissue culture and the infected cell nuclei, double-stranded DNA is formed. The radioactive signal relative to the surrounding tissue structure can be visualized by autoradiography and examined in the microscope (Fig. la).

Until recently the method could only be applied to frozen sections (Ullberg, 1977; Dubensky et al., 1984) or paraffin-embedded material (Haase et al., 1984; Brahic et al., 1984); its use was limited to soft or decalcified tissue or to whole-body cryosections of animals; this only allowing a microscopic overview but not a detailed cellular analysis at higher magnification.

(C) 1986 The Royal Microscopical Society 
a

\section{IN SITU HYBRIDIZATION-TECHNIQUE}

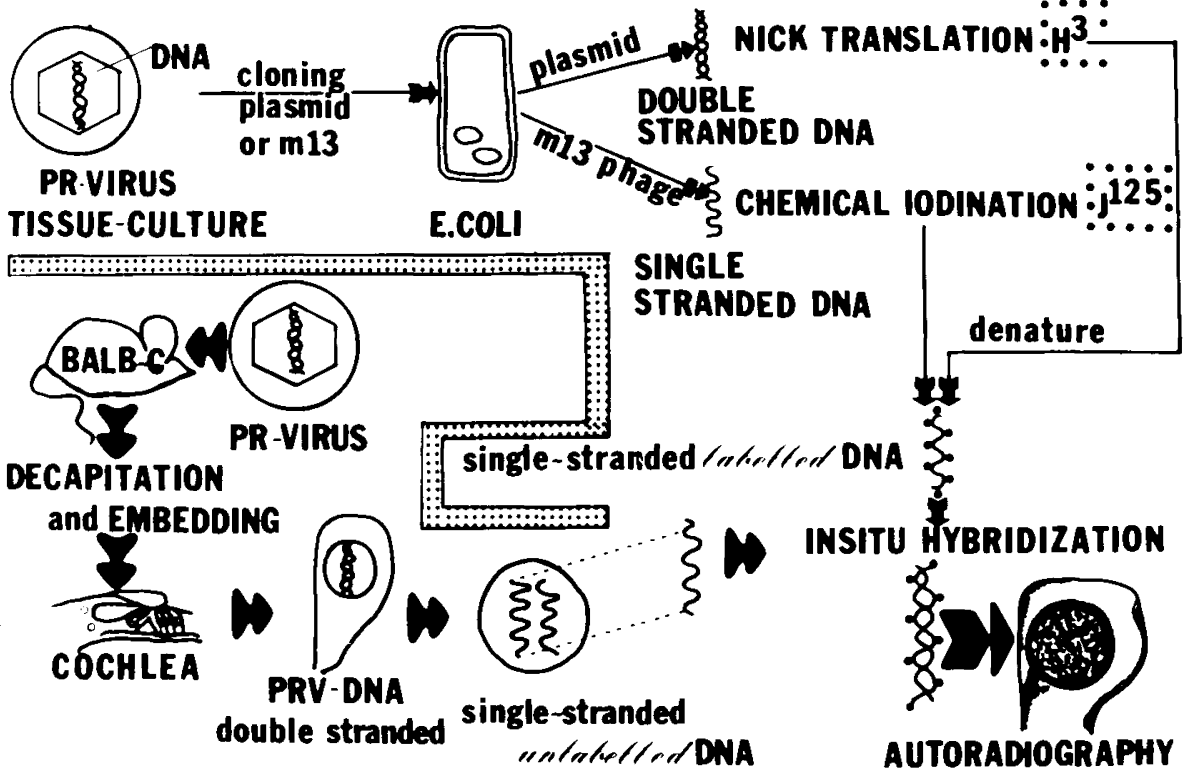

b PREPARATION OF COCHLEA IN MMA (according to H.PLENK)

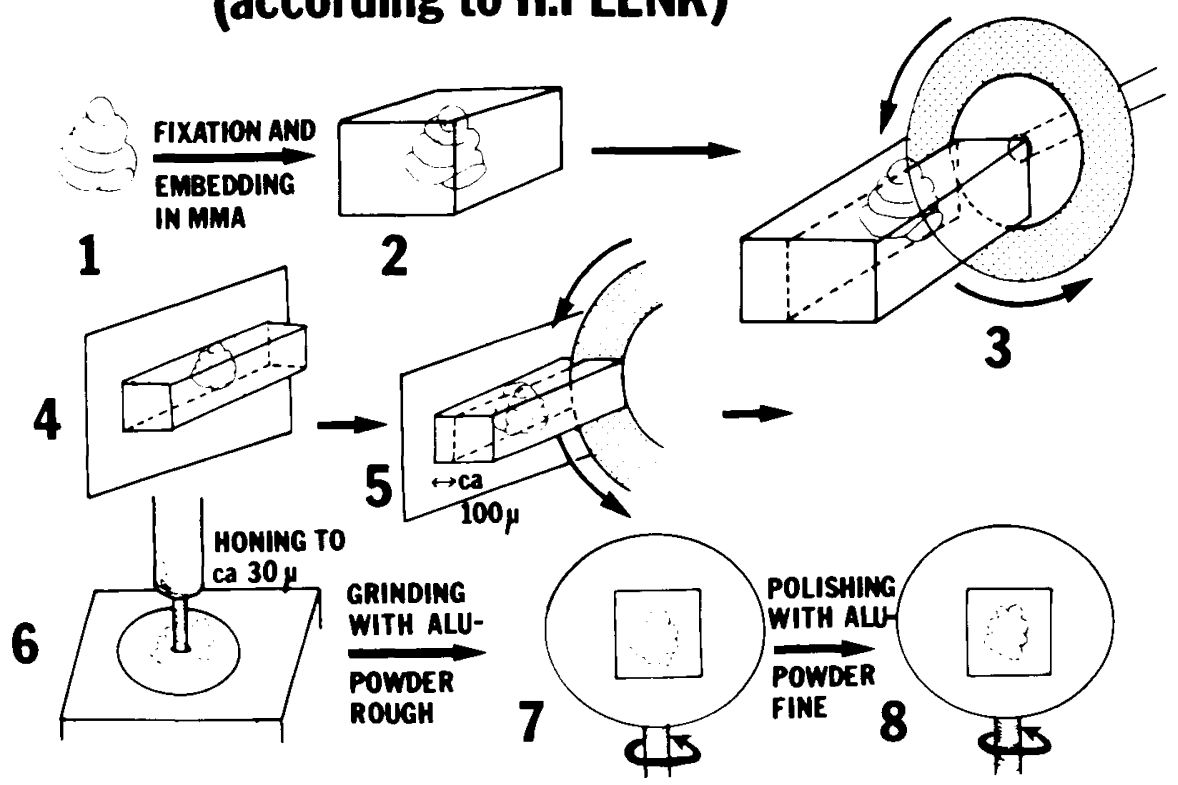

Fig. 1. (a) Diagram showing the in situ hybridization technique to identify viral DNA. (b) Diagram showing the preparation technique for methylmethacrylate embedded inner ear specimens. 
To overcome these technical limitations we had to adapt the technique of in situ hybridization to the circumstances of plastic-embedded bony material.

As an experimental model we chose the clinical picture of virus-induced labyrinthitis of the inner ear. This disease was produced by intranasally infecting the mouse with pseudorabies virus, from the herpes virus group. This virus is characterized by its neurotropism and is highly pathogenic in essentially all warm-blooded animals.

Our primary concern was the preservation and recovery of cell-components, like viral antigens, nucleic acids or enzymes, rather than the preservation of an optimal morphological structure. However, since previously published methods have not permitted embedded inner ear specimens to be made into microtome sections in a reproducible manner, the preparation technique had to be adapted to methods of bony histology like grinding and milling (Burkhardt, 1966; Boyde et al., 1978, 1981).

The second focal point of our experiments was to trace on large areas of specimens the path of the infecting virus, using the in situ hybridization technique. As an example we studied the route of PRV through the brain after intranasal infection and assessed this by cytological evidence and autoradiographic detection of the virus in situ with subsequent quantitative analysis of the hybridized sections.

\section{MATERIAL AND METHODS}

Selection of fixation procedures

A preliminary protocol of the procedures has been described elsewhere (Gu et al., 1983; Falser $e t a l ., 1985$ ). After an adequate cytopathic effect had been attained, neonatal hamster kidney cell culture suspensions, infected with pseudorabies virus, were spread onto slides. These slides were then fixed in the following solutions in routine either light or electron microscopic procedures (Hayat, 1981): Ethanol/glacial acetic acid 1:1; glutaraldehyde 2\% (alone); glutaraldehyde $2 \%+$ osmium tetroxide $1 \%$; osmium tetroxide $1 \%$ (alone); Schaffer's solution (formaldehyde/methanol 3:1); Carnoy's solution; paraformaldehyde 4\%; in each case for $20 \mathrm{~min}$ at $4^{\circ} \mathrm{C}$.

The specimens were subsequently subjected to in situ hybridization with ${ }^{3} \mathrm{H}$-labelled PRV-DNA (later) and exposed for 7 and 14 days respectively to autoradiography. After photographic development, the slides were counterstained with Ehrlich's haematoxylin.

\section{Quantitative evaluation of the autoradiograms}

All cell smears were proved with a computerized scanning microspectrophotometer based on a Univar photomicroscope (Reichert Optische Werke Vienna) using the 'Autoradiography' computer program package according to Dörmer (1967), Dörmer \& Brinkmann (1968) and Dörmer et al. (1966), using an interactive computer controlled calibration curve which, in incident light illumination with a blue interference filter (wavelength $435 \mathrm{~nm}$ ), independently provides the relationship between the silver grain density and the photometer reading. Microscale-blocks (Autoradiographic ${ }^{3} \mathrm{H}$-microscales, Amersham International plc, Code RA 501) served as standards to produce the calibration curve.

\section{Selection of the embedding medium}

The following methods from a series described and compiled in our own laboratory were short-listed and examined with respect to their suitability for inner ear research on mice cochleae from a virological point of view.

Method 1: Chemical fixation; chemical decalcification; embedding in paraffin; microtome sectioning. This standard method has been described elsewhere (Ward \& Gussen, 1976).

Method 2: Chemical fixation; plastic embedding; sectioning of the nondecalcified specimens (Spurr, 1969; Spoendlin \& Brun, 1974). 
Method 3: Cryofixation; freeze-substitution with fixative and medium; low temperature plastic embedding with Lowicryl K4M (Carlemalm et al., 1980; Rebhun, 1972), sectioning of the nondecalcified specimens on an ultramicrotome. The freshly removed cochlea from the experimental animal was split in the midsagittal plane with a fresh steel blade and immediately placed in a dewar flask, with liquid Freon-22 cooled in liquid nitrogen. After immersion for a few minutes transferred to $-80^{\circ} \mathrm{C}$ in one step. Transfer from Freon 22 to the first substitution medium (osmium tetroxide $2 \%$ dissolved in ethanol abs. at $-80^{\circ} \mathrm{C}$ )duration approx 10 days at $-80^{\circ} \mathrm{C}$-transfer to the second substitution medium (ethanol abs.) at $-80^{\circ} \mathrm{C}$ for 2 weeks. Transfer to $-30^{\circ} \mathrm{C}$ in one stage and embedding with low-temperature embedding medium Lowicryl $\mathrm{K} 4 \mathrm{M}$, by the method of Carlemalm et al. (1980). Polymerization under UV-light for 4 days at $-30^{\circ} \mathrm{C}$, subsequently 1 week at room-temperature in the absence of oxygen (nitrogen atmosphere).

Method 4: Chemical fixation; plastic embedding (methylmethacrylate or Lowicryl $\mathrm{K} 4 \mathrm{M}$ ); microscopic specimens by a precision grinding technique (a) or by a micromilling procedure (b): Dehydration and embedding of the cochlea specimens according to the method of Schenk (1965), modified according to Plenk (1976). Dehydration in stages (ethanol $96 \% 2$ days; ethanol $100 \% 4 \times 1$ day). Embedding in a mixture of methylmethacrylate $(800 \mathrm{ml})$, Plastoid $\mathrm{N}(100 \mathrm{ml})$ and Benzoylperoxide $(15 \mathrm{~g}$ or more) for 2 days at room-temperature. On the third day transferred to a water bath at $26^{\circ} \mathrm{C}$. Temperature is then raised daily by $0.5-1{ }^{\circ} \mathrm{C}$ until polymerization is attained. Hardening at $60^{\circ} \mathrm{C}$ in the incubator.

Preparation (a) (Fig. 1b). The cubic cochlea blocks, embedded in methylmethacrylate or $\mathrm{K} 4 \mathrm{M}$, were split in the mid-modiolar plane on a low-frequency precision diamond saw (11-1180 Isomet ${ }^{\text {TM }}$ Low Speed Saw, Buehler Ltd, Evanston, Ill., U.S.A.). A plexiglas-slide was then stuck on to the cut surface of the remaining half of the clamped block with a cyanoacrylate adhesive (Meteco-90 Delo-GmbH Munich) and a section parallel to the surface was made through the specimen by a parallel displacement of approximately $100 \mu \mathrm{m}$. The slide specimen (approx. $100 \mu \mathrm{m}$ thick), was then thinned down with a diamond-coated, motor driven, water-cooled buffing disk to approx. $30 \mu \mathrm{m}$ and the surface of the section was subjected to wet rotary polishing with coarse and fine-grained aluminium dust until microscopic quality was obtained.

Preparation (b). After the block (described in (a)) was split and fixed on a glass-slide the latter was clamped on to the microtome (Polycut E+Micromiller, Reichert-Jung Optische Werke) by means of a vacuum table and the specimen was reduced to a thickness of approx. $25 \mu \mathrm{m}$ using a micrometer controlled rotary diamond micromiller. Subsequently it was milled to microscopic surface quality. Final thickness approx. $13 \mu \mathrm{m}$.

Fig. 2. (a) Comparison of the silver grain density after in situ hybridization of PRV-infected BHK-cells under the influence of various fixing agents (the continuous curves illustrated are the nearest Gaussian fits to the data received). Abscissa: grain density (grain count per $100 \mu \mathrm{m}^{2}$ ); ordinate: absolute cell profile number measured. (b) The same as (2a), but with reference to the absolute silver grain count per measured nucleus profile (abscissa). (c) Comparison between 1-week and 2-week exposure of autoradiographic specimens of PRV-infected BHK-cells after fixation in 4\% paraformaldehyde and in situ PRV-DNA hybridization. (d) Example of a calibration curve for the microcytophotometric evaluation program 'autoradiography', compiled after analysis of a microscale section after 1 week's exposure. (Abscissa: optical reflectance in \%; ordinate: silver grain count per $100 \mu \mathrm{m}^{2}$.) (e) Specimen of the nasal mucosa of a PRV-infected mouse after cryofixation freezing substitution and low temperature embedding in Lowicryl K4M. Protein A-gold immunostaining with PRV-antiserum from the goat. Plain labelling of the antigen loci by gold particles (arrows). (f) Micromilled specimen of a pig's petrous bone embedded in methylmethacrylate. Thickness of specimen approx. $20 \mu \mathrm{m}$. Counterstain: Paragon. (g) Grinding specimen of a whole mouse skull (trans-sagittal) embedded in methylmethacrylate. Thickness of specimen approx. $33 \mu \mathrm{m}$. 



Fig. 2 


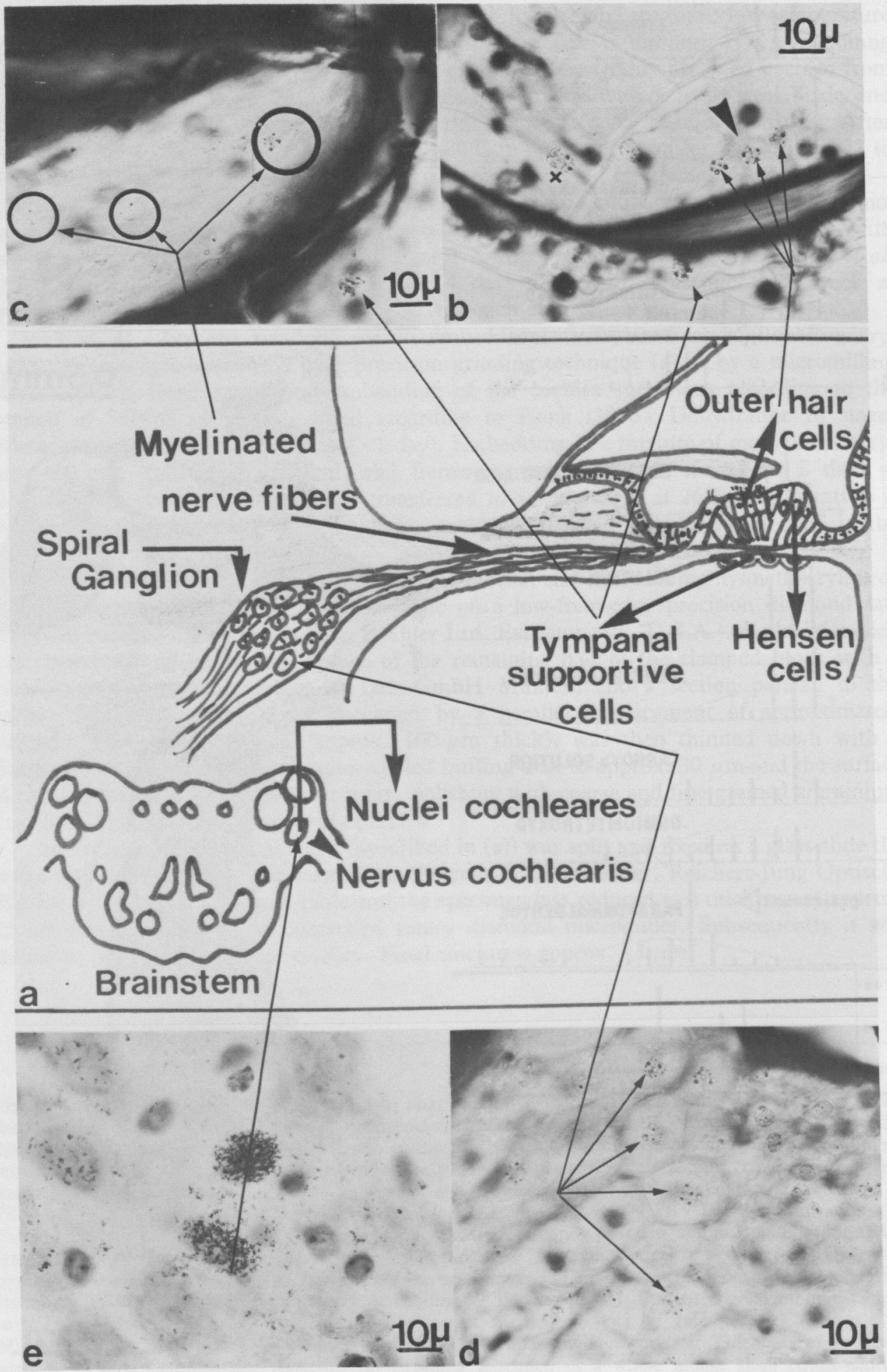

Fig. 3 


\section{Animal experiment}

(a) Virus inoculum: for the infection we used pseudorabies virus ATCC VR-135 strain Aujeszky from infected rabbit brain in $50 \%$ glycerol. Tissue culture methods, endpoint titration, etc., are described in detail elsewhere (Falser et al., 1985).

(b) Infection of experimental animals: twenty inbred BALB-C mice were infected intranasally with approx. $0.2 \mathrm{ml}$ virus suspension $\left(0.4 \times 10^{6} \mathrm{PFU}\right)$ in tissue culture medium. Four days post infection all the animals showed serious signs of illness and were then decapitated under general anaesthetic.

(c) Fixation and embedding of the experimental material. In some animals the entire skull was removed and fixed in toto, in some only the cochlea was prepared and fixed. Fixation in Schaffer's Solution (skull $24 \mathrm{~h}$, cochleae $2 \mathrm{~h}$ ). Further treatment as described in method 4.

(d) Preparation of the microscopic specimens. As described in method 4.

(e) In situ hybridization of the cochlea and skull specimens by means of ${ }^{3} \mathrm{H}-\mathrm{PRV}$-DNA (corresponds to the hybridization method for PRV infected cell smears in the preliminary fixation experiment). The PRV-DNA clones used for hybridization were kindly provided by T. Ben-Porat (Ladin et al., 1982) and were grown by H. J. Rziha (Federal Research Centre for Virus Diseases of Animals, Tübingen, F.R.G.). Labelling with ${ }^{3}$ H-CTP was carried out according to the nick-translation technique (Rigby et al., 1977). The precise details of the in situ hybridization of the PRV-DNA in the infected material to be examined (brain or inner ear) have been recorded elsewhere (Wolf et al., 1984).

Hybridization technique (alternative according to Wolf et al., 1975). The ground specimens were used directly, cell smears on slides were first treated with Denhardt's solution, incubated for $30 \mathrm{~min}$ at $70^{\circ} \mathrm{C}$ in $2 \times \mathrm{SSC}(1 \times \mathrm{SSC}=0.15 \mathrm{M} \mathrm{NaCl} ; 0.015 \mathrm{M}$ Na-citrate), $15 \mathrm{~min}$ at $37^{\circ} \mathrm{C}$ in $20 \mathrm{~mm}$ Tris $\mathrm{pH} 7 \cdot 4 ; 2 \mathrm{~mm} \mathrm{CaCl}_{2} ; 1 \mathrm{mg} / \mathrm{ml}$ proteinase $\mathrm{K}$ and dipped briefly two times in aqua dist. at room temperature. Dehydration in steps (ethanol $50 \% ; 70 \% ; 95 \%$ ) was only done for cell smear specimen before the samples were allowed to dry at room temperature.

Denaturation of DNA. The slides were submersed in $0.1 \times \mathrm{SSC}$ at $90^{\circ} \mathrm{C}$ for $30 \mathrm{~s}$, then transferred to ice-cold $0 \cdot 1 \times$ SSC followed by dehydration in steps (ethanol $50 \% ; 70 \% ; 95 \%$ ) (for the cell smears only), and air dried.

Hybridization mixture. Lyophilized, nick-translated PRV-DNA (spec. act. $1.5 \times 10^{7} \mathrm{cpm} / \mu \mathrm{g}$ ) corresponding to approx. $50,000 \mathrm{cpm} / \mathrm{slide}$, is dissolved in the following buffer: $10 \mathrm{~mm}$ Tris- $\mathrm{HCl}, \mathrm{pH} 7 \cdot 4 ; 1 \mathrm{~mm}$ EDTA; $50 \%$ formamide; $0.02 \%$ Ficoll; $0.02 \%$ PVP; $1 \mathrm{mg} / \mathrm{ml} \mathrm{BSA} ; 100 \mu \mathrm{g} / \mathrm{ml}$ calf thymus DNA; $1 \mu \mathrm{g} / \mathrm{ml} \mathrm{t}-\mathrm{RNA} ; 100 \mu \mathrm{g} / \mathrm{ml}$ poly A (according to Brahic \& Haase, 1978). This mixture is heated to $100^{\circ} \mathrm{C}$ for $2 \mathrm{~min}$, cooled in ice and supplemented to $600 \mathrm{~mm} \mathrm{NaCl}$.

In situ hybridization. $10 \mu \mathrm{l}$ of this mixture are spotted to cover an area of, covered with siliconized coverslips, sealed with 'rubber gum' and incubated for $24 \mathrm{~h}$ at $45^{\circ} \mathrm{C}$ in a water bath. After incubation, coverslips were removed and the slides rinsed briefly with $10 \mathrm{~mm}$ Tris $\mathrm{pH} 7 \cdot 4 ; 50 \%$ formamide; $1 \mathrm{~mm}$ EDTA; $600 \mathrm{~mm} \mathrm{NaCl}$ and then incubated in a fresh volume of this solution for $5 \mathrm{~min}, 2 \times 5 \mathrm{~min}$ in chloroform (does not apply to methylmethacrylate-embedded sections) $2 \times 5 \mathrm{~min}$ in $2 \times \mathrm{SSC} ; 70 \%$ ethanol $+300 \mathrm{~mm}$ ammonium acetate $90 \%$ ethanol $+300 \mathrm{~mm}$ ammonium acetate and allowed to dry in the air.

Fig. 3. (a) Diagram of anatomical structures of the inner ear. The labelling is given only for those structures where a positive sign could be substantiated after in situ DNA hybridization in PRV infected mice. (b) Silver grain accumulations in the supporting $(\times \times)$ and sensory cells $(-)$ of the organ of Corti and the tympanic laminar cells $\longrightarrow$ ) after hybridization in situ with ${ }^{3} \mathrm{H}-\mathrm{PRV}-\mathrm{DNA}$. (c) The same in the myelinated fibres of the cochlear nerve $(O)$. (d) The same in the ganglion cells of the spiral ganglion. Note the selective labelling of the ganglion cell nuclei. $(\rightarrow)$. (e) Positive virus DNA reaction in the ganglion cells of the cochlear nucleus (brain stem). 

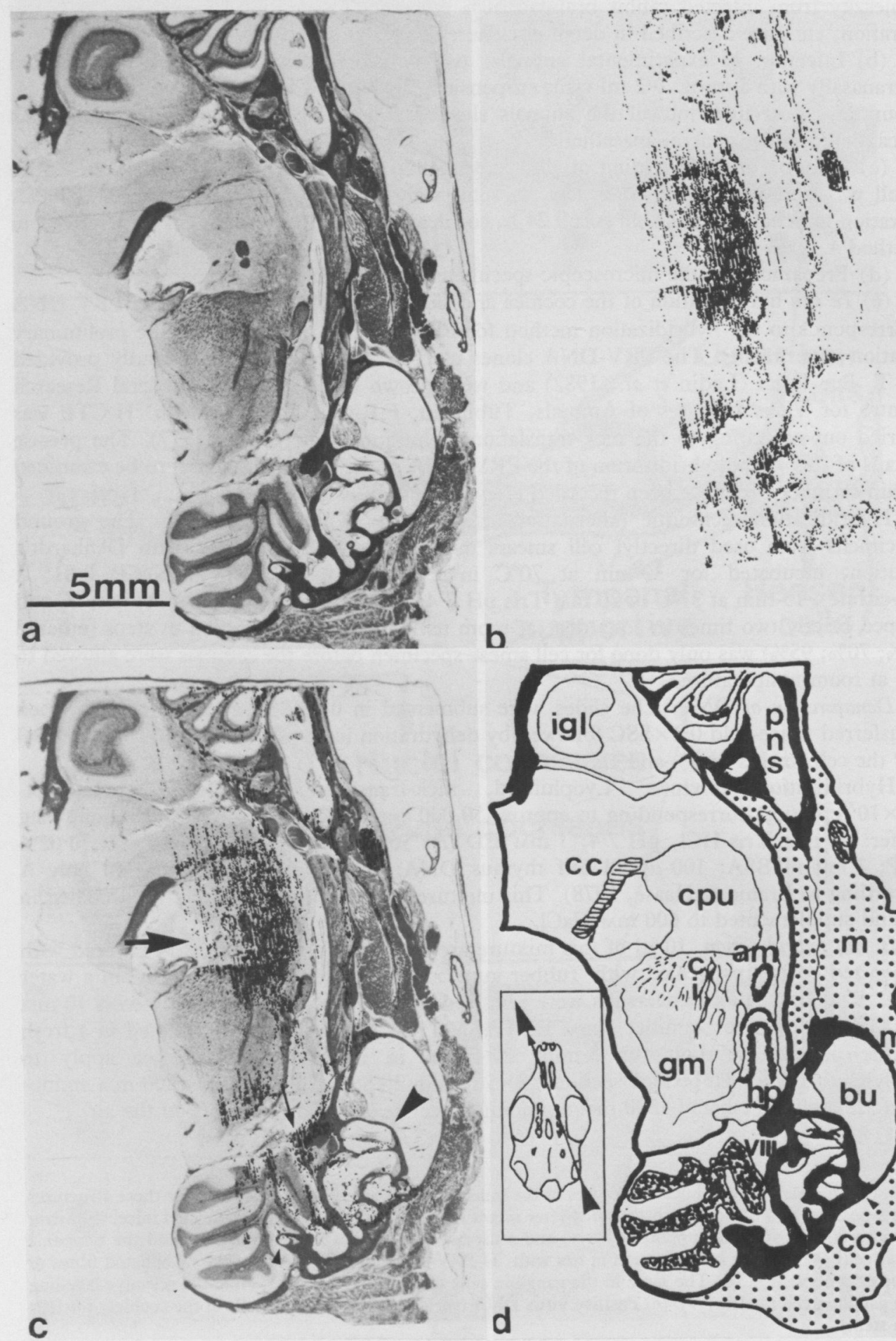

b

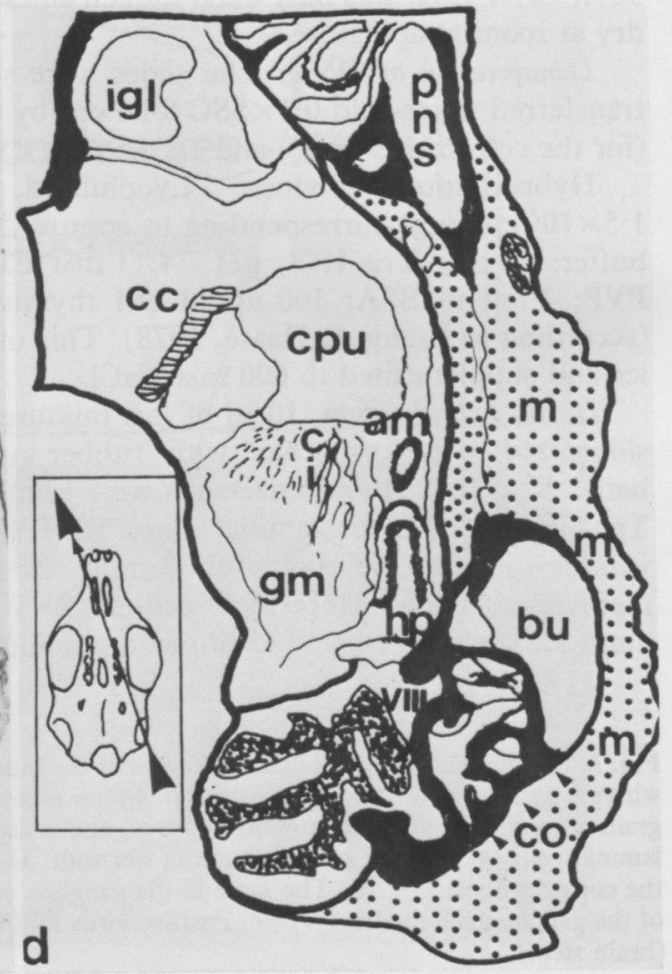

Fig. 4 
Autoradiography. $0.6 \mathrm{M}$ ammonium acetate prewarmed to $45^{\circ} \mathrm{C}$ was mixed $1: 1$ with Ilford G-5 Nuclear Emulsion Gel and kept at $45^{\circ} \mathrm{C}$. Care was taken to avoid air bubbles during mixing. The slides were briefly dipped into the diluted emulsion, allowed to drain on blotting paper and air dried. The exposure time ranged from 1 to 2 weeks (in case of cell smears) in the dark with Silicagel at $4^{\circ} \mathrm{C}$.

Photographic developments. Slides were presoaked for $5 \mathrm{~min}$ in aqua dist., developed for $6 \mathrm{~min}$ in Kodak D-19 developer rinsed in aqua dist., transferred for $2 \mathrm{~min}$ into $1 \%$ acetic acid, dipped in aqua dist., fixed for $20 \mathrm{~min}$ and allowed to wash for $20 \mathrm{~min}$ in aqua dist., before drying.

Conterstaining. Smear specimens were stained with Ehrlich's haematoxylin, ground specimens in modified Paragon-stain (basic Fuchsin-Toluidine blue at $50^{\circ} \mathrm{C}, \mathrm{pH} \mathrm{7 \cdot 4}$ ).

Controls for quality, precision and selectivity. As shown in Fig. 5.

\section{RESULTS}

\section{Fixation and embedding}

The computer-controlled, microphotometric evaluation of the in situ hybridization experiments performed on PRV-infected tissue culture cells showed clear differences of the suitability of fixing agents from routine for in situ hybridization.

Schaffer's solution displays a marked superiority in respect of nucleic acid conservation and fixation with paraformaldehyde also yields superior results. The data obtained from osmium tetroxide treated samples are also very good (Figs. $2 \mathrm{a}$ and $2 \mathrm{~b}$ ).

At least in the case of paraformaldehyde, the grain density and the absolute grain count of the autoradiographic specimens seem to follow a linear relationship to the exposure time (Fig. 2c).

The results using autoradiographic microscales allow optimal standardization of each section, to establish individual calibration curves for quantitative evaluation of the autoradiograms (Fig. 2d).

The technique finally selected by us in the main experiment, cutting with grinding or milling of chemically fixed methylmethacrylate-embedded test samples, provides satisfactory results for structure preservation and, particularly, for maintainance of in situ hybridization signals (Figs. 2f and 2g); cryofixation and cryosubstitution also ideally suitable for grinding and milling preparation, when embedded in Lowicryl K4M, are effective when simultaneous immunological experiments are required in parallel to in situ hybridization. As an example we used protein-A-gold immunostaining according to the original method of Roth et al. (1978) and Rey (1984), for the simultaneous immunoelectronmicroscopic identification of viral antigens in $\mathrm{K} 4 \mathrm{M}$-embedded nasal mucosa specimens from our experimental animals (Fig. 2e). Otherwise the technique seems too elaborate and morphologically less satisfactory when compared to methylmethacrylate-embedded material.

Fig. 4. (a) Histological specimen (toluidine blue staining) of a trans-sagittal section through the skull of a PRV-infected mouse. Methylmethacrylate embedding was used and the specimen prepared by grinding (method 4a). (b) Silver grain distribution after microcytophotometric scanning of the same ground specimen, labelled with PRV-DNA- ${ }^{3} \mathrm{H}$ after in situ hybridization. (c) Direct topographical classification of the silver grain accumulations in comparison to the neuro-anatomical structures. A massive consolidation zone can be readily recognized in the area of the rhinencephalon $(\rightarrow)$, so can a positive signal in the cochlea $(\rightarrow)$, cochlear nerve $(\rightarrow)$ and the cerebellum $(\bullet)$. (d) Diagram showing neuroanatomical structures to classify the course of infection taken by the virus DNA. Insert: Diagram showing the direction in which the methylmethacrylateembedded mouse skull was separated. The direction was in accordance with the axial direction of the cochlear modiolus. Abbreviations used: igl, internal granular layer of the olfactory bulb; pns, paranasal sinuses; cc, corpus callosum; ci, capsula interna; am, anteriomedial nucieus of the thalamus; hp, habenulo-interpeduncular tract; VIII, cochlear nerve; bu, bulla; co, cochlea and labyrinth; gm, medial geniculate body; $\mathrm{m}$, muscle. 
-

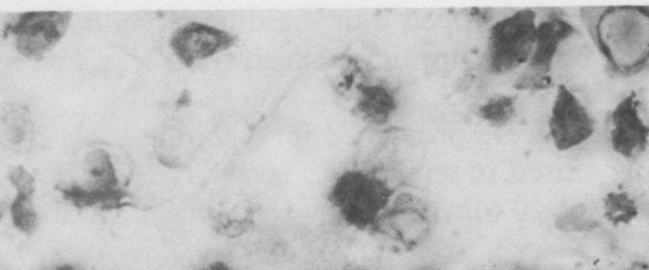

b.

a c t

C.

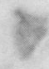

(1) 25

$\therefore \cdots$

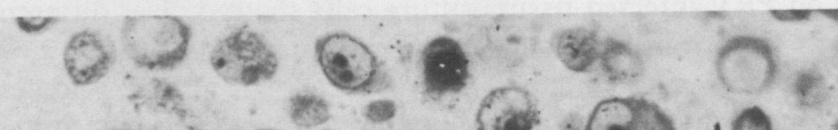

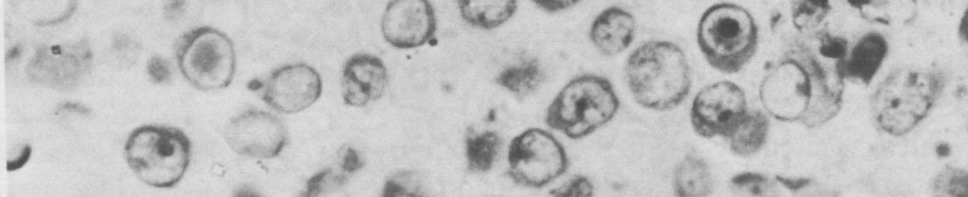

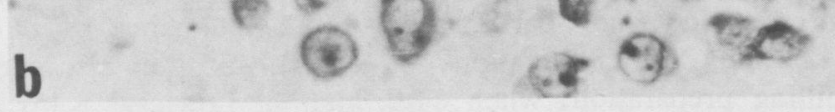

s. 18

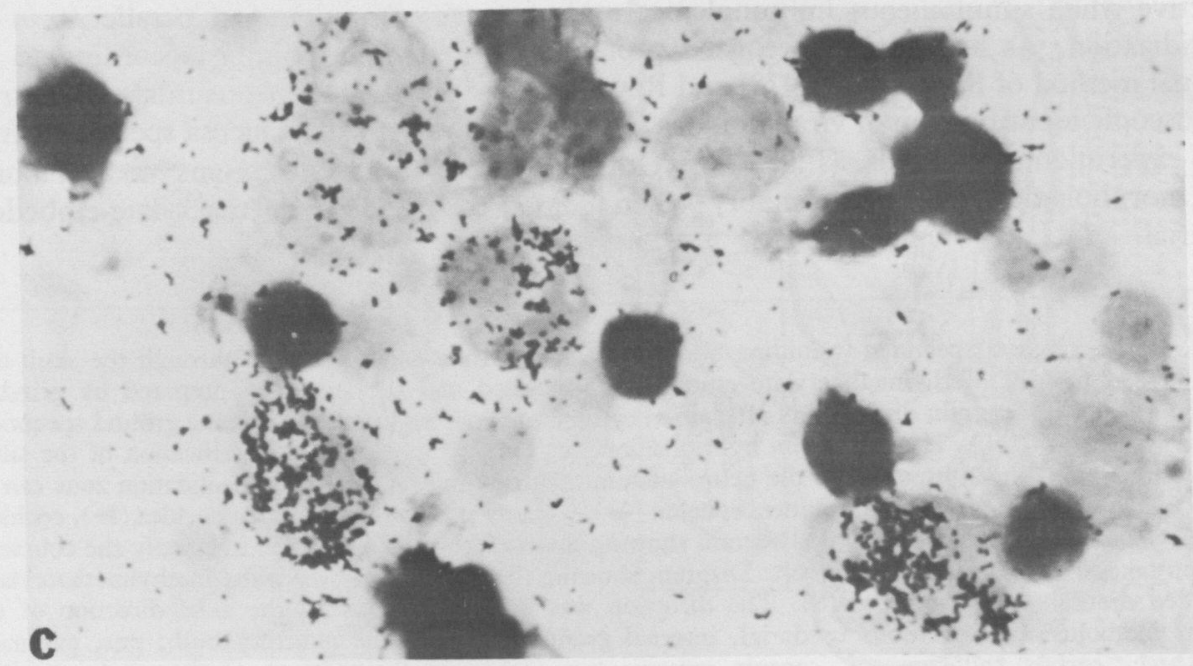

Fig. 5 
Animal experiment for identification of viral DNA in mouse brain and cochlea

When only the morphological changes are evaluated, results are of limited use for understanding pathogenicity since the detected alterations in morphology have only the quality of snapshots and are not correlated to aetiology.

Results from morphological examination can be far more reliable and interpreted as the effects of a continuous pathogenic event, if viral DNA could be detected in in situ hybridization in large area specimens (cerebrum, etc.) and, after quantitative analysis, correlated to the progress of the disease. By means of the computer-controlled microcytophotometric technique described above we analysed, as an example of such a path of infection, sagittal methylmethacrylate-embedded skull grinding specimens from the PRV-infected mouse at $\times 100$ on the scanning slide table at a stepwise distance of $20 \mu \mathrm{m}$. When compared with the relevant histological picture (toluidine-blue staining), it is possible to recognize a marked tendency of the virus infection to invade from the nasal mucosa and the mucosa of the paranasal sinuses via silver grain accumulations in the area of the rhinencephalon as far as the cerebellum, the cochlear nerve and the inner ear region (Fig. 4). A pathogenetic connection can therefore be postulated between inner ear disturbances and nasal virus infections, as suspected in humans.

Figure 3 shows the results of in situ hybridization in PRV-infected mice in the region of the petrous portion of the temporal bone (Fig. 3a), using light microscopic examination. The presence of PRV-DNA is concentrated in particular on the supporting and sensory cells (hair cells) of the Organ of Corti (Fig. 3b) and the ganglion cells of the cochlear and vestibular nerve (Figs. 3c and 3d) and can be traced as far as its nuclei in the brain stem (Fig. 3e). A significant continuity in the sense of the auditory pathway can be recognized when the results from several experimental animals are precisely followed up and seen in correlation (Stroop et al., 1984).

The quality and precision controls fully confirm the results obtained (Fig. 5).

\section{DISCUSSION}

As far as we know, these results of a successful in situ hybridization of viral DNA in fixed and embedded bony material have not been previously described; the same applies to the quantitative microphotometric analysis of in situ hybridized large specimens through the skull of experimental animals. To succeed in our test, however, various preparatory techniques had to be assessed, both with respect to virological methods and, in particular, to the preparative methods:

1. The selection of the best fixation medium. Our first choice was Schaffer's solution on account of its good compatibility with the MMA-embedding method. This material has the advantage that it can be used for immunological, enzyme histochemical and autoradiographic tests on plastified material with optimal preservation of the structure. We shall, however, pay increased attention to paraformaldehyde fixation in a combined method with immunological procedures and to osmium tetroxide as an ideal electron microscopic fixing agent.

2. The method of precision grinding and micromilling of bony structures. In our opinion, the results with the petrous portion of the temporal bone constitute a representative quality control of this method, since the constantly changing thicknesses (bony

Fig. 5. Summary of the quality and specificity controls carried out. (a) In situ hybridization with non-specific ${ }^{3} \mathrm{H}$-DNA (Epstein Barr virus) on PRV-infected BHK cells: negative result due to absence of recombination of DNA strands. (b) In situ hybridization of uninfected BHK-cells with ${ }^{3} \mathrm{H}$ labelled PRV-DNA: negative result due to absence of recombination of the DNA single strands. (c) Arrest of specific virus DNA (PRV-infected BHK-cells) by Actinomycin-D and in situ hybridization of virus DNA with specific ${ }^{3} \mathrm{H}$-labelled virus DNA (PRV): positive result due to recombination of the DNA singie strands. 
structures, interspersed with soft tissue alternating with practically empty cavities) impose the highest demands on a preparation method, just as the large area skull specimens, prepared by us do. Until now no sectioning procedure had met these demands.

Southern's (1984) recently published findings with entire body frozen sections of the virus-infected mouse are without doubt a valuable addition to the histological and preparatory equipment, but they are subject to all the sources of error and the preparatory problems characteristic of frozen section techniques (like freezing artefacts, morphological damage, etc.). It is likely to work well only when abundant hybridization signals are accessible, e.g. by massive viraemia, which is rare in nature.

Furthermore, when evaluating our specimens in comparison with frozen section material, we noticed that the rate of non-specific background in autoradiography decreases enormously in the case of plastic-embedded material. We attribute this phenomenon to the fact that the reaction of radioactively labelled viral DNA in the plastified material occurs strictly and selectively with the tissue-associated viral DNA, whereas in the case of frozen sections diffusion processes run off into the tissue, the autoradiographic identification method consequently leading to an increase in the non-specific signal.

3. The use of computer-controlled microphotometric analyses of large area tissue micropreparations. This is ideally suited to the study of the path of infection and its course; hitherto this question has remained unexplained in most viral infections, in human medicine too.

At present further experiments are underway with hydrophilic embedding agents and the required fixation procedure in order to adapt our method to an ultrastructural level. Perhaps in this way it will be possible to achieve simplified and shortened modifications to the present in situ nucleic acid hybridization method.

Here it is conceivable that the electron microscopic autoradiography technique, with all its pitfalls and its enormous time consumption, might be replaced by, for example, biotin-labelled virus DNA (Singer \& Ward, 1982). All these techniques (biotin-streptavidin identification system for electron microscopy (Nir et al., 1984)) can already be applied today to the experimental model we have developed; the particularly attractive feature of these methods seems to be the direct comparison of light and electron microscopic findings after in situ hybridization on one and the same experimental material, fixed, embedded and prepared with one and the same strategy. Although we have investigated in situ hybridization on virological problems this powerful method should also open new approaches for developmental biology, as more and more probes for specific genes are available from recombinant DNA work and can be used to detect the selective activation of genes in definable cell populations.

ACKNOWLEDGMENTS

Our special thanks are due to Professor Dr H. Plenk and Dr F. Grundschober (Histological Institute of the University of Vienna), Dr M. Scriba and colleagues (Sandoz Research Institute, Virological Department, Vienna), and Ing. Tschismarow, Ing. Hartmann, Mr Brauner, Mr Brandschowsky and Ing. Hölzl (Messrs. Reichert Optische Werke, Vienna) who paid a major contribution to the success of this study by providing apparatus and specialist advice.

\section{REFERENCES}

Boyde, A., Banes, A.J., Dillaman, R.M. \& Mechanic, G.L. (1978) A morphological study of an avian bone disorder caused by myeloblastosis-associated virus. Metab. Bone Dis. E Rel. Res. 1, $235-242$.

Boyde, A. et al. (1981) Calc. Tiss. Int. Suppl. to Vol. 33, Abstr. 43.

Brahic, M. \& Haase, A.T. (1978) Detection of viral sequences of low reteration frequency by in situ hybridization. Proc. nat. Acad. Sci. U.S.A. 75, 6125-6129.

Brahic, M., Haase, A.T. \& Cash, E. (1984) Simultaneous in situ detection of viral RNA and Antigens. Proc. nat. Acad. Sci. U.S.A. 81, 5445-5448. 
Burkhardt, R. (1966) Präparative Voraussetzungen zur klinischen Histologie des Knochenmarks. 2. Ein neues Verfahren zur histologischen Präparation aus Knochenmark und Knocken. Blut, 14, 30-46.

Carlemalm, E., Villiger, W. \& Acetarin, J.D. (1980) Advances in specimen preparation for electron microscopy. I. Novel low temperature embedding resins and a reformulated Vestopal. (Abstract). Experientia, 36, 740-743.

Dörmer, P. (1967) Auflichtphotometrische Untersuchungen zur Grösse der Koinzidenz in der Autoradiographie mit Tritium. Histochemie, 8, 1-11.

Dörmer, P. \& Brinkmann, W. (1968) Silberkornzählung mit dem Auflichtphotometer. Ein Beitrag zur quantitativen Autoradiographie. Acta histochem. Suppl. VIII, 163-172.

Dörmer, P., Stieber, W. \& Stich, W. (1966) Automatische Silberkornzählung in der EinzelzellAutoradiographie. Klin. Wschr. 44, 477-481.

Dubensky, T.W., Murphy, F.A. \& Villarreal, L.P. (1984) Detection of DNA and RNA virus genomes in organ systems of whole mice: patterns of mouse organ infection by polyomavirus. $\mathcal{F}$. Virol. 50, $779-783$.

Edwards, M.K. \& Wood, W.B. (1983) Location of specific messenger RNA's in Caenorhabditis elegans by cytological hybridization. Dev. Biol. 97, 375-390.

Falser, N., Bandtlow, I., Haus, M. \& Wolf, H. (1985) Detection of PRV-DNA in the inner ear of intranasally infected BALB-C mice with nucleic acid hybridization. $\mathcal{F}$. Virol. (in press).

Gu, S., Wolf, H. \& Yi, Z. (1983) Cloning fragments of EBV-DNA in single stranded phage $\mathrm{m} 13 \mathrm{mp} 8 . \mathrm{I}$. Preparation and identification of cloned DNA. Chinese F. Virol. 1983, 129-135.

Haase, A.T., Brahic, M., Stowring, L. \& Blum, H. (1984) Detection of viral nucleic acids by in situ hybridization. Meth. Virol. 7, 189-226.

Hayat, M.A. (1981) Fixation for Electron Microscopy, pp. 149-208. Academic Press, New York.

Ladin, B.F., Ihara, S., Hampl, H. \& Ben Porat, T. (1982) Pathway of assembly of herpesvirus capsids: an analysis using DNA temperature-sensitive mutants of pseudorabies virus. Virology, 116, 544-561.

Nir, I., Schneider, B.G. \& Papermaster, D.S. (1984) Pre-embedding labelling with biotinylated antibodies and subsequent visualization of the biotin groups exposed on thin sections. $\mathcal{F}$. Histochem. Cytochem. 32, 643-648.

Plenk, H. Jr (1976) Osteolathyrismus, pp. 4-6. Karger. Basel.

Rebhun, L.J. (1972) Freeze-substitution and freeze-drying. Principles and Techniques of Electron Microscopy, Vol. 2 (ed. by M. A. Hayat), pp. 3-49. Van Nostrand, New York.

Rey, M.E.C. (1984) Immunofluorescence and protein-A-gold techniques in localization of plant pathogen antigens in Lowicryl K4M embedded tissue. F. Microsc. 136, 373-381.

Rigby, P.W.J., Dieckmann, M., Rhodes, C. \& Berg, P. (1977) Labelling deoxyribonucleic acid to high specific activity in vitro by nick-translation with DNA-polymerase I. F. molec. Biol. 113, 237-251.

Roth, J., Bendayan, M. \& Orci, L. (1978) Ultrastructural localization of intracellular antigens by the use of protein-A-gold complex. F. Histochem. Cytochem. 26, 1074-1081.

Schenk, R. (1965) Zur histologischen Verarbeitung von unentkalkten Knochen. Acta anat. 60, 3-19.

Singer, R.H. \& Ward, D.C. (1982) Actin gene expression visualized in chicken muscle tissue culture by using in situ hybridization with a biotinated nucleotide analog. Proc. nat. Acad. Sci. U.S.A. 79, 7331-7335.

Southern, P.J., Blount, P. \& Oldstone, M.B.A. (1984) Analysis of persistent virus infections by in situ hybridization to whole-mouse sections. Nature, 312, 555-558.

Spoendlin, H. \& Brun, J.P. (1974) The block-surface technique for evaluation of cochlear pathology. Arch. Oto-Rhino-Laryngol. 208, 137-145.

Spurr, A.R. (1969) A low-viscosity epoxy resin embedding medium for electron microscopy. $\mathcal{F}$. Ultrastruct. Res. 26, 31-43.

Stroop, W.G., Rock, D.L. \& Fraser, N.W. (1984) Localization of Herpes simplex virus in the trigeminal and olfactory systems of the mouse central nervous system during acute and latent infections by in situ hybridization. Lab. Invest. 51, 27-38.

Ullberg, S. (1977) The technique of whole body autoradiography. Cryosectioning of large specimens. Science Tools, Special Issue, pp. 2-30.

Ward, P.H. \& Gussen, R. (1976) Preparation of the temporal bone for histopathological study. Handbook of Auditory and Vestibular Research Methods (ed. by C. Smith and J. A. Vernon), pp. 53-71. Charles C. Thomas, Springfield, Ill.

Wolf, H., zur Hausen, H. \& Becker, V. (1973) EB viral genomes in epithelial nasopharyngeal carcinoma cells. Nature: New Biol. 138, 245-247.

Wolf, H., zur Hausen, H., Klein, G., Becker, V., Henle, G. \& Henle, W. (1975) Attempts to detect virusspecific DNA sequences in human tumors. III. Epstein Barr viral DNA in non-lymphoid nasopharyngeal carcinoma cells. Med. Microbiol. Immunol. 161, 15-21.

Wolf, H., Haus, M. \& Wilmes E. (1984) Persistence of Epstein-Barr virus in the parotid gland. F. Virol. 51, 795-798. 